medRxiv preprint doi: https://doi.org/10.1101/2020.11.14.20231142; this version posted November 16, 2020. The copyright holder for this preprint (which was not certified by peer review) is the author/funder, who has granted medRxiv a license to display the preprint in It is made available under a CC-BY-NC 4.0 International license .

\title{
Capability impacts of the Covid-19 lockdown in association with mental well-being, social connections and existing vulnerabilities: an Austrian survey study
}

Judit Simon ${ }^{1,2}$, Timea M. Helter ${ }^{1}$, Ross G. White ${ }^{3}$, Catharina van der Boor ${ }^{3}$, Agata Laszewska $^{1}$

${ }^{1}$ Department of Health Economics, Center for Public Health, Medical University of Vienna,

Kinderspitalgasse 15, 1090 Vienna, Austria

${ }^{2}$ Department of Psychiatry, University of Oxford, Warneford Hospital, Oxford OX3 7JX, UK

${ }^{3}$ Primary Care and Mental Health, Institute of Population Health, University of Liverpool, School of Psychology, Brownlow Hill, Liverpool, L69 3GB, UK

\section{Corresponding Author}

Judit Simon, Department of Health Economics, Center for Public Health, Medical University of Vienna, Kinderspitalgasse 15, 1090 Vienna, Austria; Phone: +43 140160 34841; E-Mail:

judit.simon@meduniwien.ac.at

NOTE: This preprint reports new research that has not been certified by peer review and should not be used to guide clinical practice. 
medRxiv preprint doi: https://doi.org/10.1101/2020.11.14.20231142; this version posted November 16, 2020. The copyright holder for this preprint (which was not certified by peer review) is the author/funder, who has granted medRxiv a license to display the preprint in

It is made available under a CC-BY-NC 4.0 International license .

\begin{abstract}
Background: Impacts of the Covid-19 pandemic and its public health measures go beyond physical and mental health and incorporate wider well-being impacts in terms of what people are free to do or be. We explored these capability impacts of the Covid-19 lockdown in association with people's mental well-being, social support and existing vulnerabilities in Austria.
\end{abstract}

Methods: Adult Austrian residents $(\mathrm{n}=560)$ provided responses to a cross-sectional online survey about their experiences during Covid-19 lockdown (15 March-15 April 2020). Instruments measuring capabilities (OxCAP-MH), depression and anxiety (HADS), social support (MSPSS) and mental well-being (WHO-5) were used in association with six pre-defined vulnerabilities using multivariable linear regression.

Results: $31 \%$ of the participants reported low mental well-being and only $30 \%$ of those with a history of mental health treatment received treatment during lockdown. Past mental health treatment had a significant negative effect across all outcome measures with an associated capability well-being score reduction of -6.54 (95\%CI: -9.26,-3.82). Direct Covid-19 experience and being 'at risk' due to age and/or physical health conditions were also associated with significant capability deprivations. When adjusted for vulnerabilities, significant capability reductions were observed in association with increased levels of depression (-1.79) and anxiety (-1.50), and significantly higher capability levels $(+3.77)$ were associated with higher levels of social support. Compared to the cohort average, individual capability impacts varied between $-9 \%$ for those reporting past mental health treatment and $+5 \%$ for those reporting one score higher on the social support scale.

Conclusions: Our study is the first to assess the capability limiting aspects of a lockdown in association with specific vulnerabilities. The negative impacts of the Covid-19 lockdown were strongest for people with a history of mental health treatment. In future public health policies, special attention should be also paid to improving social support levels to increase public resilience.

Keywords: Covid-19, Austria, Capabilities, Well-being, Mental health, OxCAP-MH, Vulnerability, Resilience 
medRxiv preprint doi: https://doi.org/10.1101/2020.11.14.20231142; this version posted November 16,2020 . The copyright holder for this preprint (which was not certified by peer review) is the author/funder, who has granted medRxiv a license to display the preprint in It is made available under a CC-BY-NC 4.0 International license .

\section{Introduction}

The recently discovered coronavirus, known as severe acute respiratory syndrome coronavirus 2 (SARSCoV-2), has spread globally within a span of a few months since December 2019 [1]. The Covid-19 disease caused by the virus was declared as a pandemic by the World Health Organisation (WHO) on $11^{\text {th }}$ March 2020. Initial evidence suggested that the infection has a high effective reproduction rate and older populations and those with underlying health conditions are at high risk of severe disease and death, thereby forcing numerous countries into temporary lockdowns to limit the spread of the disease. Consequently, the Covid-19 pandemic went from a direct health emergency to a systemic crisis affecting people's lives in multiple ways [2]. The Covid-19 impacts are unprecedented because of its evolution from a health shock to a global economic and social crisis [2].

Substantial evidence from the past studies of the impacts of Severe Acute Respiratory Syndrome, Middle East Respiratory Syndrome, and Ebola epidemics on the suffering individuals and the healthcare providers showed substantial neuropsychiatric linkage [3]. There is an increasing amount of research related to the impacts Covid-19 on people's mental health and well-being [3-22]. Beside the direct health impact, public health emergencies may also affect individuals and communities through isolation, stigma, job insecurity, or inadequate resources for medical response [15]. These effects generate a range of emotional reactions, and are expected to be particularly prevalent among those individuals who contract the disease, or are at increased risk due to their age or pre-existing medical conditions [15]. Evidence from previous pandemics shows that individuals who contract the disease experience fear, anxiety, emotional distress, and post-trauma stress symptoms [3]. The mental health/well-being impacts of the pandemic can be even more significant for those who are prone to psychological problems [6].

Impacts of this pandemic and its public health measures go beyond physical and mental health and incorporate wider well-being impacts in terms of what people are free to do or be. Due to these complexities, the assessment of personal consequences related to well-being is challenging and may be best addressed within the conceptual framework of the capability approach introduced by Amartya Sen 
medRxiv preprint doi: https://doi.org/10.1101/2020.11.14.20231142; this version posted November $16,2020$. The copyright holder for this preprint (which was not certified by peer review) is the author/funder, who has granted medRxiv a license to display the preprint in It is made available under a CC-BY-NC 4.0 International license .

in the early 1980s [23]. The capability approach proposes that well-being is determined by people's freedom to engage in forms of being and doing that are of intrinsic value to the person [23]. Beside the recently proposed use of the capability framework in the understanding of policy challenges [24], this freedom aspect can be interpreted in the narrower mental health context as both the actual capabilities of a person, for instance, good mental health, and the processes that enable them, for instance, legal regulations [25]. Not only has the Covid-19 outbreak had a profound psychological impact, but it also affects personal freedoms to engage in behaviours that are consistent with subjectively held values, for instance, visiting loved ones, engaging in recreational activities, spending time outdoors. Despite these important links, the connection between pandemics and individual capabilities have not yet been researched.

In Europe, Austria stood out as a nation that adopted aggressive and early strategies and thereby saw a smaller proportion of deaths from Covid-19 compared to some other European countries [26]. The first Covid-19 case in Austria was reported on 25 February 2020 [27]. The Austrian government issued general laws to contain the epidemic by restricting social contacts and imposing strict lockdown measures from 16 March onwards [27] most of which have been lifted gradually since 15 April. Early studies assessing the Covid-19 and related public health measures impacts have found significant impact on the mental health of the Austrian population. The studies found that symptoms of moderate to severe anxiety and depression have tripled in Austria, and 8-13\% of the population showed severe depression and $6-11 \%$ severe anxiety symptoms $[28,29]$.

Despite the increasing number of studies exploring the Covid-19 impact on mental health/well-being, information is missing on the broader capability impact of the pandemic. Hence, this study aimed to explore the impact the Covid-19 lockdown period on people's capabilities in association with mental health/well-being and social support, especially in the case of specific vulnerable groups in Austria. Vulnerable groups were pre-defined: (i) being categorised as 'at risk' group based on age and/or preexisting physical health conditions; (ii) self-reported mental health treatment prior to the coronavirus pandemic; (iii) direct exposure to Covid-19 (having symptoms or being tested positive); (iv) indirect 
medRxiv preprint doi: https://doi.org/10.1101/2020.11.14.20231142; this version posted November 16,2020 . The copyright holder for this preprint (which was not certified by peer review) is the author/funder, who has granted medRxiv a license to display the preprint in It is made available under a CC-BY-NC 4.0 International license.

exposure to Covid-19 through a family member/friend; (v) having employment status impacted by the lockdown; or (vi) being categorised as critical worker.

\section{Methods}

\section{Study design, data collection and participants}

Cross-sectional data were collected via an online survey in May/June 2020, with all questions, including standardised outcome instruments, referring to the one-month lockdown period in Austria between 15 March and 15 April 2020.

Participants were recruited using convenience sampling. Adults ( $\geq 18$ years), with sufficient German knowledge, access to the online survey, and residency in Austria at the time of the Covid-19 outbreak were able to participate. The survey was developed in the SoSci online survey platform (Version 2), which is a publicly available tool and is free of charge for academic research [30]. The weblink of the survey was included in an advert, along with a QR code, that was circulated via social media platforms (including Facebook, Twitter, WhatsApp, etc.) and emails targeting a wide range of individuals and organisations throughout Austria.

Respondents who provided sociodemographic and Covid-19-related information and completed at least one standardised instrument were considered for analysis. Those participants who discontinued the survey before fully completing at least one standardised instrument were excluded from the analyses.

\section{Survey and instruments}

The online survey consisted of the participant information and consent forms followed by a section on sociodemographics. Subsequent sections assessed people's perceptions about the Covid-19 outbreak and the public health measures in place during the lockdown in Austria in response to the outbreak. The final 
medRxiv preprint doi: https://doi.org/10.1101/2020.11.14.20231142; this version posted November $16,2020$. The copyright holder for this preprint (which was not certified by peer review) is the author/funder, who has granted medRxiv a license to display the preprint in

part of the questionnaire consisted of four self-reported standardised and validated outcome instruments, which were used to assess capability well-being (OxCAP-MH), depression and anxiety levels (HADS), social support (MSPSS) and mental well-being (WHO-5) similar to a parallel linked survey in the UK [31].

The Oxford CAPabilities questionnaire-Mental Health (OxCAP-MH) instrument was developed by Simon et al. in 2013 [32]. It is specifically designed to capture different well-being dimensions within the capability framework in the area of mental health across 16 items. The OxCAP-MH is scored on a 0-100 scale, with higher scores indicating better capabilities. The German version of the OxCAP-MH [33] was obtained from the authors for the study.

The Hospital Anxiety and Depression Scale (HADS) was developed by Zigmond and Snaith in 1983 [34]. The HADS was found to perform well in assessing the presence and severity of anxiety disorders and depression, also beyond the hospital setting, including the general population [35]. The questionnaire is divided into Anxiety (HADS-A) and Depression (HADS-D) subscales both containing seven items scored on a four-point scale from zero (not present) to three (considerable). Both the HADSA and HADS-D subscales are scored from 0-21, with higher scores indicating higher anxiety or depression levels. Normal, borderline and abnormal anxiety/depression scores are defined as 0-7, 8-10 and 11-21, respectively [34]. The German translation of HADS was obtained from Hogrefe Publishing Group.

The Multidimensional Scale of Perceived Social Support (MSPSS) is a self-reported measure of subjectively assessed social support developed by Zimet et al. in 1988 [36]. The questionnaire can be divided into three subscales, each addressing a different source of support: Family, Friends, and Significant Other. Low, moderate and high support are defined as $<3,3-5$ and $>5$, respectively [36]. An official German translation of MSPSS was obtained from the developer of the original English version.

The World Health Organisation-Five Well-being Index (WHO-5) is a short self-reported measure of current mental well-being introduced in 1998 by the WHO Regional Office in Europe [37]. Respondents are asked to rate how well each of the five statements about positive well-being applied to them in the given period from 5 (all of the time) to 0 (none of the time). The WHO-5 is scored 0-25, with higher 
medRxiv preprint doi: https://doi.org/10.1101/2020.11.14.20231142; this version posted November 16,2020 . The copyright holder for this preprint (which was not certified by peer review) is the author/funder, who has granted medRxiv a license to display the preprint in It is made available under a CC-BY-NC 4.0 International license .

scores representing higher well-being [38]. The German translation of the WHO-5 is available in the public domain without registration.

\section{Statistical analysis}

Anonymous data were extracted from the online survey and checked for logical inconsistencies. Six hypothesised associations between higher levels of mental health symptoms and lower levels of wellbeing were tested for pre-defined vulnerabilities: i) At risk group; ii) Past mental health treatment; iii) Direct Covid-19 experience; iv) Indirect Covid-19 experience; v) Employment status affected by Covid19; and vii) Critical worker.

Individuals were defined as 'at risk' if they were aged 65 years or over and/or had a self-reported underlying physical health condition including diabetes, heart/cardiovascular disease, stroke/cerebrovascular disease, lung disease, liver disease, or cancer. Participants who reported mental health service use prior to the period of interest were categorised as 'having past mental health treatment'. Participants with 'direct Covid-19 experience' were those who tested positive for Covid-19 or experienced Covid-19 symptoms, but were not tested. 'Indirect Covid-19 experience' was defined as having a friend and/or family member infected or knowing someone who died of Covid-19. Participants with 'employment status affected' were those who reported losing their job due to the pandemic or being sent to short-time working (German 'Kurzarbeit'). Finally, participants who reported having a job categorised by the government as critical worker, e.g. healthcare staff, police officer or food supply worker, were defined as 'critical workers'.

Correlations between the different outcome measures were explored using Pearson's correlations and interpreted as small $<0.3$, moderate $0.3-0.49$, or large $\geq 0.50$ [39]. In order to explore the impacts of the Covid-19 lockdown on capabilities, mental health/well-being and social support in association with predefined vulnerabilities, multivariable linear regression analyses were conducted using the OxCAP-MH, HADS-D, HADS-A, MSPSS and WHO-5 scores as dependent variables and binary vulnerable group 
medRxiv preprint doi: https://doi.org/10.1101/2020.11.14.20231142; this version posted November $16,2020$. The copyright holder for this preprint (which was not certified by peer review) is the author/funder, who has granted medRxiv a license to display the preprint in It is made available under a CC-BY-NC 4.0 International license.

defining variables as independent variables. Analyses were adjusted for age, gender, having children, education level and initial employment status.

The magnitude of impact of current depression, anxiety and social connections on capabilities was investigated separately in a multivariable regression analysis adjusted for all measured sociodemographic characteristics and pre-defined vulnerabilities. Significance level of $p<0.05$ was considered in all analyses. Analyses were conducted on complete cases in STATA v.15.1 [40].

\section{Results}

\section{Participant characteristics}

848 persons accessed the survey, out of whom 560 respondents ( $74.1 \%$ female, mean age 40.2 years) completed it and was included in the analyses (Figure 1). The average time needed to complete the survey was 17 minutes.

[FIGURE 1]

The majority of participants were Austrian citizens (87\%) and employed at the beginning of the Covid19 lockdown (73\%). More than half of the survey participants (56\%) had children, 52\% were married or had a registered partnership. Full data on sociodemographic characteristics in comparison to the official Austrian population statistics, with respect to age, gender, distribution of population across federal states [41], migration background [42], education level [43], and employment status [44], are shown in Table 1.

[TABLE 1] 
medRxiv preprint doi: https://doi.org/10.1101/2020.11.14.20231142; this version posted November 16,2020 . The copyright holder for this preprint (which was not certified by peer review) is the author/funder, who has granted medRxiv a license to display the preprint in It is made available under a CC-BY-NC 4.0 International license .

\section{Vulnerabilities}

A total of $13 \%$ of the respondents $(n=72)$ were categorised as belonging to the 'at risk' group based on age and/or co-existing physical health conditions. While $17 \%$ of the participants $(n=97)$ reported that they received treatment for mental disorders before the period of interest, only $6 \%$ of the participants $(n=34)$ reported receiving mental health treatment during the pandemic. Overall, only $30 \%$ of those with a mental health service use history $(\mathrm{n}=29)$ reported receiving treatment also during the lockdown.

A total of $1 \%$ of participants $(n=7)$ had been diagnosed with Covid-19, another $6 \%(n=32)$ of the participants experienced Covid-19-like symptoms without being tested, and $20 \%$ of the respondents $(\mathrm{n}=110)$ had indirect Covid-19 experience through an infected friend and/or family member, or knew someone who died of Covid-19. Employment status was affected for $15 \%(n=84)$ of participants (job terminated: $3 \%, \mathrm{n}=15$; short-term work: $12 \%, \mathrm{n}=69)$, and $38 \%$ of the respondents $(\mathrm{n}=214)$ reported having a job categorised as 'critical worker' (Table 1).

The level of missing values for the standardised outcome instruments was low with a maximum of ten observations missing (1.8\%) for the outcome measures MSPSS and WHO-5. Mean OxCAP-MH score was $74.1(\mathrm{SD}=12.3)$. Mean WHO-5 score was $15.1(\mathrm{SD}=4.8)$ with $31 \%(\mathrm{n}=174)$ of the respondents reporting a score below 13 indicating low mental well-being [37]. The mean scores on HADS-A and HADS-D subscales were $6.3(\mathrm{SD}=4.2)$ and $4.7(\mathrm{SD}=4.1)$, respectively, indicating that respondents on average reported higher levels of anxiety than depression symptoms. A total of $74 \%$ of participants $(n=416)$ reached the threshold of $>5$ for high social support on the MPSS scale. Average scores for the MSPSS subscales were 5.41 for family support, 5.53 for support from friends and 5.96 for support from significant others.

\section{Correlations between capability well-being, mental health/well-being and social support outcomes}

Capability well-being (OxCAP-MH) was signficantly strongly/moderately associated with all other outcome measures, the strongest correlation being with depression (HADS-D: r=-0.64, HADS-A: r=- 
medRxiv preprint doi: https://doi.org/10.1101/2020.11.14.20231142; this version posted November 16,2020 . The copyright holder for this preprint (which was not certified by peer review) is the author/funder, who has granted medRxiv a license to display the preprint in It is made available under a CC-BY-NC 4.0 International license .

0.56, WHO-5: $r=0.58$, MSPSS: $r=0.42$ ). In terms of social support, capabilities and depression had the same strenght of correlations, but of opposite directions. (Table 2).

[TABLE 2]

\section{Outcome associations with different types of vulnerability}

Outcome associations with different types of vulnerabilities adjusted for sociodemographics are shown in Table 3. Past mental health treatment had a significant negative effect across all outcome measures with an associated capability well-being score reduction of -6.54 (95\%CI: -9.26, -3.82), while direct Covid-19 experience had the second most detrimental impact with an associated capability well-being score reduction of -4.58 (95\%CI: $-8.54,-0.62)$. Capabilities were similarly negatively affected also for those who belonged to the category 'at risk' $(-4.45,95 \% \mathrm{CI}$ : $-7.68,-1.21)$. These correspond to capability deprivations of $-9 \%$ and $-6 \%$, respectively, when compared to the average capability level of the study cohort.

Having employment status affected by the pandemic produced consistently lower capability and mental well-being scores as well as higher depression and anxiety scores, but these associations did not reach statistical significance. We could not observe any significant impacts for the category 'critical worker' either.

[TABLE 3]

\section{Associations between capability well-being and current depression, anxiety and social support levels}

Additional associations between current levels of depression and anxiety as well as social support with capability well-being were investigated in a separate multivariable regression analysis adjusted for all vulnerabilities and sociodemographics (Table 4). Current levels of depression and anxiety separately showed a capability score reduction of -1.79 (95\%CI: $-1.99,-1.59)$ and -1.50 (95\%CI: $-1.71,-1.29)$, 
medRxiv preprint doi: https://doi.org/10.1101/2020.11.14.20231142; this version posted November 16,2020 . The copyright holder for this preprint (which was not certified by peer review) is the author/funder, who has granted medRxiv a license to display the preprint in It is made available under a CC-BY-NC 4.0 International license .

respectively, per one point difference in the relevant HADS scores. Social support on the other hand proved to be a major capability resilience factor. One point score improvement on the MSPSS scale was associated with an improvement of +3.77 (95\% CI: 3.02, 4.53) in the capability scores.

[TABLE 4]

\section{Discussion}

This is the first study to assess the impact of the Covid-19 lockdown on capabilities in association with mental health/well-being, social support and with different specific vulnerabilities as observed in Austria.

Our findings that Covid-19 direct experience is associated with intensified anxiety symptoms, lower mental well-being and lower capabilities is in line with other recent studies exploring the impact of the Covid-19 pandemic on mental health and well-being in Austria [28, 29, 45-47]. Our study showed that participants who reported mental health treatment before the Covid-19 pandemic reported worse outcomes on all measures, including the OxCAP-MH, HADS-D, HADS-A, MSPSS and WHO-5. However, only the OxCAP-MH capability questionnaire showed a significant negative impact for participants categorised as belonging to the 'at risk' group. This association has not been captured by any other outcome measure, suggesting an increased sensitivity of the OxCAP-MH in comparison to the other scales used in this study and confirming the advantage of its broader measurement scope when assessing the well-being impact of a pandemic and related public health measures. The study also confirmed that the capability approach, which provides an indication of people's freedom to engage in forms of being and doing that are of intrinsic value to the person, has direct relevance to situations/policies that inherently limit personal freedoms, i.e. public health emergencies.

The vulnerabilities referred to in this study as 'employment status affected' by Covid-19 or being a 'critical worker' were not significantly associated with any of the outcomes. Besides the issue of sample size, it may also reflect the Austrian government's employment support policy implemented in the early stages of the pandemic including the introduction of the short-term working scheme to help retain jobs $[48,49]$. 
medRxiv preprint doi: https://doi.org/10.1101/2020.11.14.20231142; this version posted November $16,2020$. The copyright holder for this preprint (which was not certified by peer review) is the author/funder, who has granted medRxiv a license to display the preprint in It is made available under a CC-BY-NC 4.0 International license .

When considering the average capability well-being score observed in our cohort, the relative impact of different vulnerabilities and other factors on capability levels were estimated between $-9 \%$ for those reporting past mental health treatment vs. $+5 \%$ for reporting one score higher on the social support scale. In future analyses, the outcome scores obtained in this study could also be compared to scores observed in studies prior to the Covid-19 pandemic to further asses the overall impact of this public health emergency and lockdown on the well-being of the Austrian population. Previous studies using the WHO-5 instrument found that $26-27 \%$ of the Austrian sample reported scores corresponding to low mental well-being $[50,51]$. This is lower than the $31 \%$ of respondents who were identified as having low mental well-being (WHO-5 score below 13) in our study. Furthermore, 19\% of the participants in this study had borderline and $16 \%$ 'abnormal' anxiety levels according to HADS-A scoring system, somewhat higher than the levels reported in earlier Austrian studies [52-55]. These results seem to be confirmative of the expected negative impacts of the Covid-19 pandemic, including those of the lockdown, on mental well-being including increased levels of anxiety and stress. Previous studies using the MSPSS scale in Austrian populations reported comparable scores, indicating relatively high social support [56, 57].

In addition to providing an indication of the Covid-19 and lockdown impacts on vulnerable groups, this study also presents the interactions between capability well-being levels and current mental health indicating a strong negative impact of current depression and anxiety. On the other hand, social support was shown as a major capability resilience factor. Future (public health) policies should take the strong associations between capabilities and current mental health and social support levels directly into consideration to minimise the negative long-term health, social and economic issues related to future public health emergencies.

Furthermore, our results suggest that amongst all investigated vulnerabilities, people with past mental health treatment represent the most vulnerable group. A recent study from Austria found that the number of people treated with psychotherapy during lockdown (personal, phone or virtual contacts) decreased by one-third [58]. In our study, the proportion of people receiving mental health treatment during lockdown in comparison to the period before the pandemic was $6 \%$ vs. $17 \%$, respectively. We found 
medRxiv preprint doi: https://doi.org/10.1101/2020.11.14.20231142; this version posted November $16,2020$. The copyright holder for this preprint (which was not certified by peer review) is the author/funder, who has granted medRxiv a license to display the preprint in It is made available under a CC-BY-NC 4.0 International license .

indication for treatment continuation between the two periods for only $30 \%$ of those participants who received mental health treatment prior to the pandemic. Even under the most conservative assumptions, these results suggest a substantial level of underutilisation of mental health services (due to whatever causes) during the lockdown period. For future strategic healthcare planning during next waves of the pandemic, policy makers and health and social care providers need to be aware of the exceptional vulnerability of this group and efforts have to be made for continuous mental health service provision. Digital e-health treatment options provide potential solution to assure the continuity of treatment and at the same time protect health of the service-users and professionals $[59,60]$.

The main limitation of our study is that the participants completed the survey retrospectively about one month after the lockdown (mid-May 2020). This time lag may have introduced some recall bias considering the self-reported outcome measures. Since data were collected at the time when the number of new Covid-19 cases were relatively low and the Austrian epidemic curve has flattened, we assume that the presented estimates are more conservative and optimistic than if the survey questions would have been completed directly during the lockdown. Moreover, since the analysis is based on one measurement point, the study allows no causal conclusions. Our study is also prone to limitations of online survey; results are based fully on self-reporting with the potential to reporting bias [61] and some groups (females, younger ages, higher educated), were over-represented in the survey sample compared to the general population $[62,63]$. The survey on the other hand achieved satisfactory representation in terms of more than half of the Austrian provinces, migration background and employment status.

\section{Conclusions}

This research contributes to the understanding of the impact that pandemics and nationwide responses to pandemics can have on mental health and broader capability well-beings in light of their major policy relevance. Furthermore, the study confirms that the OxCAP-MH capability measure is a valid and relevant tool to understand the impacts of the Covid-19 pandemic and related public health measures which due to the negative externalities of any infectious disease inherently limit individual freedoms to some extent. Future research is planned to compare cultural aspects of lockdown experiences across 
medRxiv preprint doi: https://doi.org/10.1101/2020.11.14.20231142; this version posted November $16,2020$. The copyright holder for this preprint (which was not certified by peer review) is the author/funder, who has granted medRxiv a license to display the preprint in It is made available under a CC-BY-NC 4.0 International license.

countries and explore long-term mental health/well-being impacts from the perspective of the capability approach.

\section{List of abbreviations}

HADS - The Hospital Anxiety and Depression Scale

MSPSS - The Multidimensional Scale of Perceived Social Support

OxCAP-MH - The Oxford CAPabilities questionnaire-Mental Health

WHO - World Health Organisation

WHO-5 - The World Health Organisation-Five Well-being Index

\section{Declarations}

Ethical approval and consent to participate: All procedures performed in studies involving human participants were in accordance with the ethical standards of the Ethics Commission of the Medical University of Vienna (EK 1529/2020) and with the 1964 Helsinki declaration and its later amendments or comparable ethical standards. Informed consent was obtained from all individual participants included in the study.

Consent for publication: Not applicable.

Availability of data and materials: The dataset generated during the current study and the study protocol have been released in a scientific data repository and can be accessed under the link: https://doi.org/10.5281/zenodo.4271534. 
medRxiv preprint doi: https://doi.org/10.1101/2020.11.14.20231142; this version posted November 16, 2020. The copyright holder for this preprint (which was not certified by peer review) is the author/funder, who has granted medRxiv a license to display the preprint in

It is made available under a CC-BY-NC 4.0 International license .

Competing interests: JS has led the development of the OxCAP-MH measure. The remaining authors declare that they have no conflict of interest.

Funding: The study received no funding.

Authors' contributions: JS, RW and CV conceived the study idea, and developed the conceptual framework and methods of the research. JS provided the resources to this study. TH and AL executed the survey and conducted the analysis supervised by JS. JS, TH and AL wrote the manuscript which was reviewed by all. All authors provided critical feedback and helped shape the research, analysis and manuscript. All authors approved the final manuscript.

Acknowledgements: We would like to say thank you to all survey participants and to colleagues at the Department of Health Economics for piloting the survey.

\section{References}

1. WHO. WHO Coronavirus Disease (COVID-19) Dashboard. 2020. https://covid19.who.int/. Accessed 30 Oct 2020.

2. UNDP. COVID-19 and human development: Assessing the crisis, envisioning the recovery. 2020. http://hdr.undp.org/en/hdp-covid. Accessed 30 Oct 2020.

3. Shah K, Kamrai D, Mekala H, Mann B, Desai K, Patel RS. Focus on Mental Health During the Coronavirus (COVID-19) Pandemic: Applying Learnings from the Past Outbreaks. Cureus. 2020;12(3):e7405.

4. Caqueo-Urízar A, Urzúa A, Aragón-Caqueo D, Charles CH, El-Khatib Z, Otu A, et al. Mental health and the COVID-19 pandemic in Chile. Psychol Trauma. 2020;12(5):521-3.

5. Chen S, Bonanno GA. Psychological adjustment during the global outbreak of COVID-19: A resilience perspective. Psychol Trauma. 2020;12(S1):S51-S4.

6. Cullen W, Gulati G, Kelly BD. Mental health in the COVID-19 pandemic. QJM. 2020;113(5):311-2.

7. Dong L, Bouey J. Public Mental Health Crisis during COVID-19 Pandemic, China. Emerg Infect Dis. 2020;26(7):1616-8.

8. Javed B, Sarwer A, Soto EB, Mashwani ZU. The coronavirus (COVID-19) pandemic's impact on mental health. Int J Health Plann Manage. 2020.

9. Kavčič T, Avsec A, Zager Kocjan G. Psychological Functioning of Slovene Adults during the COVID-19 Pandemic: Does Resilience Matter? Psychiatr Q. 2020:1-10.

10. Khoury B, El-Khoury J, Ammar J. Psychological needs and response during the COVID-19 pandemic in Lebanon. Psychol Trauma. 2020;12(5):497-8.

11. Koushik NS. A population mental health perspective on the impact of COVID-19. Psychol Trauma. 2020;12(5):529-30.

12. Lai J, Ma S, Wang Y, Cai Z, Hu J, Wei N, et al. Factors Associated With Mental Health Outcomes Among Health Care Workers Exposed to Coronavirus Disease 2019. JAMA Netw Open. 2020;3(3):e203976.

13. Loades ME, Chatburn E, Higson-Sweeney N, Reynolds S, Shafran R, Brigden A, et al. Rapid Systematic Review: The Impact of Social Isolation and Loneliness on the Mental Health of Children 
medRxiv preprint doi: https://doi.org/10.1101/2020.11.14.20231142; this version posted November 16, 2020. The copyright holder for this preprint (which was not certified by peer review) is the author/funder, who has granted medRxiv a license to display the preprint in

It is made available under a CC-BY-NC 4.0 International license .

and Adolescents in the Context of COVID-19. J Am Acad Child Adolesc Psychiatry. 2020;S08908567(20)30337-3.

14. Mancini AD. Heterogeneous mental health consequences of COVID-19: Costs and benefits. Psychol Trauma. 2020;12(S1):S15-S6.

15. Pfefferbaum B, North CS. Mental Health and the Covid-19 Pandemic. N Engl J Med. 2020;383(6):510-2.

16. Rossi R, Socci V, Talevi D, Mensi S, Niolu C, Pacitti F, et al. COVID-19 pandemic and lockdown measures impact on mental health among the general population in Italy. Front Psychiatry. 2020;11:790.

17. Seghi F, Barbini B, Franchini L, Colombo C. The challenge of mental health during Covid-19 outbreak: experience from metropolitan area of Milan. Eur Arch Psychiatry Clin Neurosci. 2020:1-2.

18. Serafini G, Parmigiani B, Amerio A, Aguglia A, Sher L, Amore M. The psychological impact of COVID-19 on the mental health in the general population. QJM. 2020;113(8):531-7.

19. Sher L. The impact of the COVID-19 pandemic on suicide rates. QJM. 2020; hcaa202.

20. Talevi D, Socci V, Carai M, Carnaghi G, Faleri S, Trebbi E, et al. Mental health outcomes of the CoViD-19 pandemic. Rivista di psichiatria. 2020;55(3):137-44.

21. Tang F, Liang J, Zhang H, Kelifa MM, He Q, Wang P. COVID-19 related depression and anxiety among quarantined respondents. Psychol Health. 2020:1-15.

22. Torales J, O'Higgins M, Castaldelli-Maia JM, Ventriglio A. The outbreak of COVID-19 coronavirus and its impact on global mental health. Int J Soc Psychiatry. 2020;66(4):317-20.

23. Sen A. Commodities and capabilities: OUP Catalogue; 1999.

24. Sen A. Capability and well-being. In: Nusbaum M, Sen A, editors. The Quality of Life: Oxford: Clarendon Press; 1993. p. 30-53.

25. Anand P, Ferrer B, Gao Q, Nogales R, Unterhalter E. COVID-19 as a capability crisis: using the capability framework to understand policy challenges. J Human Dev Capabil. 2020:293-9.

26. Gibney E. Whose coronavirus strategy worked best? Scientists hunt most effective policies. Nature. 2020;581(7806):15-6.

27. Moshammer H, Poteser M, Lemmerer K, Wallner P, Hutter HP. Time Course of COVID-19 Cases in Austria. Int J Environ Res Public Health. 2020;17(9).

28. Pieh C, Budimir S, Probst T. Mental Health during COVID-19 Lockdown: A Comparison of Austria and the UK Available at SSRN 3592372. 2020.

29. Traunmüller C, Stefitz R, Gaisbachgrabner K, Schwerdtfeger A. Psychological correlates of COVID-19 pandemic in the Austrian population. BMC Public Health. 2020.

30. Leiner DJ. SoSci Survey (Version 3.1.06) [Computer software] 2019.

[https://www.soscisurvey.de.

31. White RG, Van Der Boor C. Impact of the COVID-19 pandemic and initial period of lockdown on the mental health and well-being of adults in the UK. BJPsych Open. 2020;6(5):e90.

32. Simon J, Anand P, Gray A, Rugkåsa J, Yeeles K, Burns T. Operationalising the capability approach for outcome measurement in mental health research. Soc Sci Med. 2013;98:187-96.

33. Simon J, Łaszewska A, Leutner E, Spiel G, Churchman D, Mayer S. Cultural and linguistic transferability of the multi-dimensional OxCAP-MH capability instrument for outcome measurement in mental health: the German language version. BMC Psychiatry. 2018;18(1):173.

34. Snaith RP, Zigmond AS. The hospital anxiety and depression scale. Br Med J (Clin Res Ed). 1986;292(6516):344.

35. Bjelland I, Dahl AA, Haug TT, Neckelmann D. The validity of the Hospital Anxiety and Depression Scale. An updated literature review. J Psychosom Res. 2002;52(2):69-77.

36. Zimet GD, Dahlem NW, Zimet SG, Farley GK. The Multidimensional Scale of Perceived Social Support. J Pers Assess. 1988;52(1):30-41.

37. WHO. Well-being Measures in Primary Health Care/The Depcare Project. Report on a WHO Meeting. Europe WROf, editor. Copenhagen 1998.

38. Topp CW, Østergaard SD, Søndergaard S, Bech P. The WHO-5 Well-Being Index: a systematic review of the literature. Psychother Psychosom. 2015;84(3):167-76.

39. Cohen J. Statistical power analysis for the behavioral sciences.: Erbaum Press, Hillsdale, NJ, USA; 1988.

40. StataCorp. Stata Statistical Software: Release 15. College Station, TX: StataCorp LLC. 2017. 
medRxiv preprint doi: https://doi.org/10.1101/2020.11.14.20231142; this version posted November 16, 2020. The copyright holder for this preprint (which was not certified by peer review) is the author/funder, who has granted medRxiv a license to display the preprint in

It is made available under a CC-BY-NC 4.0 International license .

41. Statistik Austria. Bevölkerung am 1.1.2019 nach Alter und Bundesland. 2019.

http://www.statistik.at/web_de/statistiken/menschen_und_gesellschaft/bevoelkerung/bevoelkerungsstr uktur/bevoelkerung_nach_alter_geschlecht/023470.html. Accessed 30 Oct 2020.

42. Statistik Austria. Bevölkerung 2017 nach detaillierter Staatsangehörigkeit, Geschlecht und Bundesland. 2017.

http://www.statistik.at/web de/statistiken/menschen und gesellschaft/bevoelkerung/volkszaehlungen registerzaehlungen abgestimmte erwerbsstatistik/bevoelkerung nach demographischen merkmalen /index.html Accessed 30 Oct 2020.

43. Statistik Austria. Bildungsstand der Bevölkerung ab 15 Jahren 2017 nach Altersgruppen und Geschlecht. 2017.

http://www.statistik.at/web_de/statistiken/menschen_und_gesellschaft/bildung/bildungsstand_der_bev oelkerung/121189.html. Accessed 30 Oct 2020.

44. Statistik Austria. Austria: Data. Figures. Facts.; 2020.

http://www.statistik.at/wcm/idc/idcplg?IdcService=GET_NATIVE_FILE\&dDocName=029252.

Accessed 30 Oct 2020.

45. Braun M, Niederkronenthaler T, Till B. SARS CoV-2: Mental Health in Österreich

Ausgewählte Ergebnisse zur ersten Befragungswelle, 23.04.-05.05.2020. Unit Suizidforschung und Mental Health Promotion, Abteilung für Sozial- und Präventivmedizin, Zentrum für Public Health, Medizinische Universität Wien; 2020.

46. Nitschke JP, Forbes, P., Ali, N., Cutler, J., Apps, M. A. J., Lockwood, P., \& Lamm, C. .

Resilience during uncertainty? Greater social connectedness during COVID-19 lockdown is associated with reduced distress and fatigue. Br J Health Psychol. 2020.

47. Stieger S, Lewetz, D., \& Swami, V. Psychological Well-Being Under Conditions of Lockdown: An Experience Sampling Study in Austria During the COVID-19 Pandemic. PsyArXiv Preprints. 2020.

48. Hofer H, Titelbach G, Fink M. Die österreichische Arbeitsmarktpolitik vor dem Hintergrund der Covid-19-Krise. Institute for Advanced Studies, Vienna, Austria; 2020.

https://irihs.ihs.ac.at/id/eprint/5388/7/ihs-report-2020-hofer-titelbach-fink-oesterreicharbeitsmarktpolitik-covid-19.pdf.

49. Müller M. The start of the Austrian response to the COVID-19 crisis: a personal account. Wien Klin Wochenschr. 2020;132(13-14):353-5.

50. de Wit L, Jelsma JG, van Poppel MN, Bogaerts A, Simmons D, Desoye G, et al. Physical activity, depressed mood and pregnancy worries in European obese pregnant women: results from the DALI study. BMC Pregnancy Childbirth. 2015;15:158.

51. Loder AKF, Schwerdtfeger AR, van Poppel MNM. Perceived greenness at home and at university are independently associated with mental health. BMC Public Health. 2020;20(1):802. 52. Cenik F, Keilani M, Hasenöhrl T, Huber D, Stuhlpfarrer B, Pataraia A, et al. Relevant parameters for recommendations of physical activity in patients suffering from multiple myeloma: A pilot study. Wien Klin Wochenschr. 2020;132:124-31.

53. Clever K, Schepper F, Pletschko T, Herschbach P, Christiansen H, Martini J. Psychometric properties of the Fear of Progression Questionnaire for parents of children with cancer (FoP-QSF/PR). J Psychosom Res. 2018;107:7-13.

54. Herrmann C, Buss U. Snaith RP: Hospital Anxiety and Depression Scale-Deutsche Version (HADS-D). Verlag Hans Huber: Ein Fragebogen zur Erfassung von Angst und Depressivität; 1995.

55. Sipötz J, Friedrich O, Höfer S, Benzer W, Chatsakos T, Gaul G, et al. Health related quality of life and mental distress after PCI: restoring a state of equilibrium. Health Qual Life Outcomes. 2013;11:144.

56. Greimel E, Kato Y, Müller-Gartner M, Salchinger B, Roth R, Freidl W. Internal and External Resources as Determinants of Health and Quality of Life. PLoS One. 2016;11(5):e0153232.

57. Mautner E, Ashida C, Greimel E, Lang U, Kolman C, Alton D, et al. Are there differences in the health outcomes of mothers in Europe and East-Asia? A cross-cultural health survey. Biomed Res Int. 2014;2014:856543.

58. Probst T, Stippl P, Pieh C. Changes in Provision of Psychotherapy in the Early Weeks of the COVID-19 Lockdown in Austria. Int J Environ Res Public Health. 2020;17(11):3815. 
medRxiv preprint doi: https://doi.org/10.1101/2020.11.14.20231142; this version posted November 16, 2020. The copyright holder for this preprint (which was not certified by peer review) is the author/funder, who has granted medRxiv a license to display the preprint in

It is made available under a CC-BY-NC 4.0 International license .

59. Tullio V, Perrone G, Bilotta C, Lanzarone A, Argo A. Psychological support and psychotherapy via digital devices in Covid-19 emergency time: Some critical issues. Medico-Legal Journal. 2020;88(2):73-6.

60. Van Daele T, Karekla M, Kassianos AP, Compare A, Haddouk L, Salgado J, et al. Recommendations for policy and practice of telepsychotherapy and e-mental health in Europe and beyond. J Psychother Integr. 2020;30(2):160.

61. Devaux M, Sassi F. Social disparities in hazardous alcohol use: self-report bias may lead to incorrect estimates. Eur J Public Health. 2016;26(1):129-34.

62. Mulder J, de Bruijne M. Willingness of Online Respondents to Participate in Alternative Modes of Data Collection. Survey Practice. 2019;12(1).

63. Yetter G, Capaccioli K. Differences in responses to Web and paper surveys among school professionals. Behav Res Methods. 2010;42(1):266-72. 
medRxiv preprint doi: https://doi.org/10.1101/2020.11.14.20231142; this version posted November 16, 2020. The copyright holder for this preprint (which was not certified by peer review) is the author/funder, who has granted medRxiv a license to display the preprint in

It is made available under a CC-BY-NC 4.0 International license .

\section{Tables and Figures}

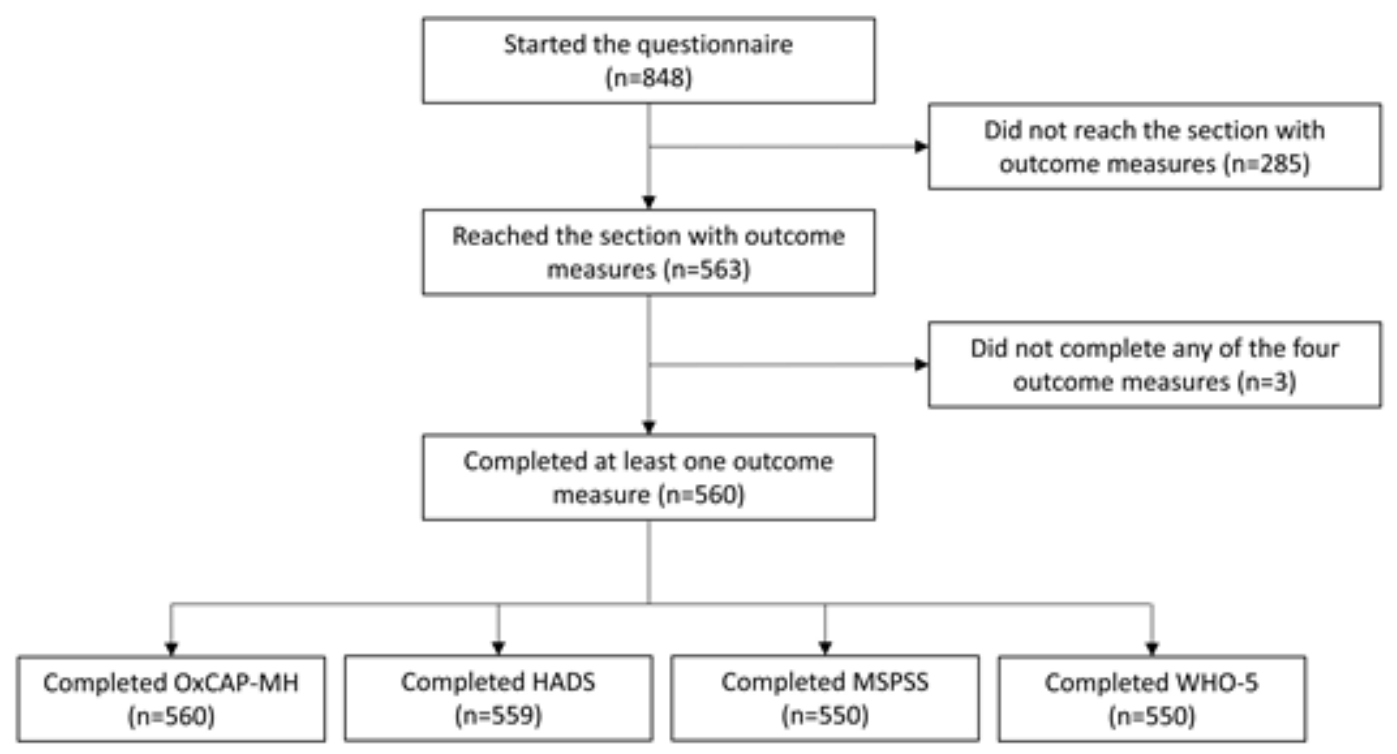

Figure 1. Survey flowchart 
medRxiv preprint doi: https://doi.org/10.1101/2020.11.14.20231142; this version posted November 16, 2020. The copyright holder for this preprint (which was not certified by peer review) is the author/funder, who has granted medRxiv a license to display the preprint in

It is made available under a CC-BY-NC 4.0 International license .

Table 1. Characteristics of the survey cohort

\begin{tabular}{|c|c|c|c|}
\hline & \multicolumn{2}{|c|}{$\begin{array}{c}\text { Covid-19 Study } \\
n=560\end{array}$} & \multirow{2}{*}{$\begin{array}{c}\begin{array}{c}\text { Austrian } \\
\text { population }\end{array} \\
\%\end{array}$} \\
\hline & $\mathrm{n}$ & $\%$ & \\
\hline \multicolumn{4}{|l|}{ Gender } \\
\hline Female & 416 & $74 \%$ & $51 \%$ \\
\hline Male & 143 & $26 \%$ & $49 \%$ \\
\hline Diverse & 1 & $0 \%$ & \\
\hline Missing & 0 & $0 \%$ & \\
\hline \multicolumn{4}{|l|}{ Age } \\
\hline $18-29$ & 97 & $17 \%$ & $18 \%$ \\
\hline $30-49$ & 319 & $57 \%$ & $34 \%$ \\
\hline $50-64$ & 124 & $22 \%$ & $26 \%$ \\
\hline $65-79$ & 13 & $2 \%$ & $23 \%$ \\
\hline Missing & 7 & $1 \%$ & \\
\hline \multicolumn{4}{|l|}{ Federal state } \\
\hline Burgenland & 12 & $2 \%$ & $3 \%$ \\
\hline Carinthia & 41 & $7 \%$ & $6 \%$ \\
\hline Lower Austria & 109 & $19 \%$ & $19 \%$ \\
\hline Upper Austria & 66 & $12 \%$ & $17 \%$ \\
\hline Salzburg & 25 & $4 \%$ & $6 \%$ \\
\hline Styria & 63 & $11 \%$ & $14 \%$ \\
\hline Tyrol & 24 & $4 \%$ & $9 \%$ \\
\hline Vorarlberg & 5 & $1 \%$ & $4 \%$ \\
\hline Vienna & 215 & $38 \%$ & $21 \%$ \\
\hline Missing & 0 & $0 \%$ & \\
\hline \multicolumn{4}{|l|}{ Migration background } \\
\hline EU-Members before 2004/EWR/Switzerland & 33 & $6 \%$ & $3 \%$ \\
\hline EU-Members joined 2004 and after & 14 & $3 \%$ & $5 \%$ \\
\hline Former Yugoslavia (not-EU), Turkey & 7 & $1 \%$ & $3 \%$ \\
\hline Other countries & 12 & $2 \%$ & $5 \%$ \\
\hline Austrian roots & 489 & $87 \%$ & $84 \%$ \\
\hline Missing & 5 & $1 \%$ & \\
\hline \multicolumn{4}{|l|}{ Education } \\
\hline Primary education & 13 & $2 \%$ & $26 \%$ \\
\hline Vocational school for apprentices & 68 & $12 \%$ & $32 \%$ \\
\hline Intermediate technical and vocational school & 45 & $8 \%$ & $14 \%$ \\
\hline General secondary education and vocational colleges & 132 & $24 \%$ & $15 \%$ \\
\hline Higher education & 302 & $54 \%$ & $13 \%$ \\
\hline Missing & 0 & $0 \%$ & \\
\hline \multicolumn{4}{|l|}{ Employment status } \\
\hline Housekeeping & 28 & $5 \%$ & $2 \%$ \\
\hline Student & 37 & $7 \%$ & $4 \%$ \\
\hline Employed & 410 & $73 \%$ & $64 \%$ \\
\hline Self-employed & 37 & $7 \%$ & $9 \%$ \\
\hline Unemployed & 16 & $3 \%$ & $2 \%$ \\
\hline Retired & 25 & $4 \%$ & $19 \%$ \\
\hline Missing & 7 & $1 \%$ & \\
\hline \multicolumn{4}{|l|}{ Family status } \\
\hline Single & 204 & $36 \%$ & \\
\hline Married or registered partnership, living together & 266 & $48 \%$ & \\
\hline Married or registered partnership, living separately & 20 & $4 \%$ & \\
\hline Widowed & 6 & $1 \%$ & \\
\hline Divorced & 46 & $8 \%$ & \\
\hline Missing & 18 & $3 \%$ & \\
\hline \multicolumn{4}{|l|}{ Children } \\
\hline Yes & 311 & $56 \%$ & \\
\hline No & 245 & $44 \%$ & \\
\hline
\end{tabular}


medRxiv preprint doi: https://doi.org/10.1101/2020.11.14.20231142; this version posted November 16,2020 . The copyright holder for this preprint (which was not certified by peer review) is the author/funder, who has granted medRxiv a license to display the preprint in

It is made available under a CC-BY-NC 4.0 International license .

Missing

Categorised as 'at risk' group ${ }^{1}$

Yes

No

Missing

Received mental health treatment before the pandemic

Yes

No

Missing

Received mental health treatment during the pandemic lockdown

Yes

No

Missing

Direct Covid-19 experience

Tested positive for Covid-19

Experienced symptoms of Covid-19, not tested Missing

Indirect Covid-19 experience ${ }^{2}$

Close friend tested positive for Covid-19

Family member tested positive for Covid-19

Knew someone who died of Covid-19

Missing

Employment status affected by Covid-19

Fired from job

Short-time working

Missing

Critical worker

Yes

No

Missing

OxCAP-MH score (mean, SD)

Missing

HADS-D (mean, SD)

HADS depression score normal (0-7)

HADS depression score borderline (8-10)

HADS depression score abnormal (11-21)

Missing

HADS-A (mean, SD)

HADS anxiety score normal (0-7)

HADS anxiety score borderline (8-10)

HADS anxiety score abnormal (11-21)

Missing

MSPSS score (mean, SD)

MSPSS high support (5.1-7)

MSPSS moderate support (3-5)

MSPSS low support (0-2.99)

Missing

WHO-5 score (mean, SD) Missing

Note:

${ }^{1}$ Participants were categorised as 'at risk' group if they were aged 65 or more, and/or they self-reported at least one of the listed diseases: heart/cardiovascular disease, stroke/cerebrovascular disease, lung disease (e.g. asthma, cystic fibrosis, COPD), liver disease (e.g. hepatitis), cancer;

${ }^{2}$ Respondents included in "direct Covid-19 experience" variable were excluded from this group

$\begin{array}{rr}4 & 1 \% \\ 72 & 13 \% \\ 486 & 87 \% \\ 2 & 0 \% \\ & \\ 97 & 17 \% \\ 456 & 81 \% \\ 7 & 1 \%\end{array}$

$34 \quad 6 \%$

$518 \quad 93 \%$

$-7-1 \%$

$39 \quad 7 \%$

$7 \quad 1 \%$

$32 \quad 6 \%$

$110 \quad 20 \%$

$46 \quad 9 \%$

$32 \quad 6 \%$

$44 \quad 8 \%$

$0 \quad 0 \%$

$84 \quad 15 \%$

$15 \quad 3 \%$

$69 \quad 12 \%$

$6 \quad 1 \%$

$214 \quad 38 \%$

$330 \quad 59 \%$

$4.72 \quad 4.09$

$436 \quad 78 \%$

$62 \quad 11 \%$

$61 \quad 11 \%$

$10 \%$

$6.26 \quad 4.19$

$362 \quad 65 \%$

$108 \quad 19 \%$

$89 \quad 16 \%$

$10 \%$

$416 \quad 74 \%$

$112 \quad 20 \%$

$22 \quad 4 \%$

$10 \quad 2 \%$

$15.1 \quad 4.8$

$10 \quad 2 \%$
$16 \quad 3 \%$

$74.1 \quad 12.3$

$0 \quad 0 \%$ 
medRxiv preprint doi: https://doi.org/10.1101/2020.11.14.20231142; this version posted November $16,2020$. The copyright holder for this preprint (which was not certified by peer review) is the author/funder, who has granted medRxiv a license to display the preprint in

It is made available under a CC-BY-NC 4.0 International license .

Table 2. Correlations between capability well-being, mental health/well-being and social support outcomes

\begin{tabular}{llllll}
\hline & OxCAP-MH & HADS-D & HADS-A & MSPSS & WHO-5 \\
\hline OxCAP-MH & 1 & & & & \\
HADS-D & $-0.64 * * *$ & 1 & & & \\
HADS-A & $-0.56 * * *$ & $0.75 * * *$ & 1 & & \\
MSPSS & $0.42 * * *$ & $-0.42 * * *$ & $-0.30 * * *$ & 1 & \\
WHO-5 & $0.58 * * *$ & $-0.70 * * *$ & $-0.67 * * *$ & $0.34 * * *$ & 1 \\
\hline
\end{tabular}

Note: $* \mathrm{p}<0.05, * * \mathrm{p}<0.01, * * * \mathrm{p}<0.001$; OxCAP-MH - Oxford CAPabilities questionnaire-Mental Health; HADS-D Hospital Anxiety and Depression Scale Depression subscale; HADS-A - Hospital Anxiety and Depression Scale Anxiety subscale; MSPSS - Multidimensional Scale of Perceived Social Support; WHO-5 - World Health Organisation-Five Wellbeing Index 
medRxiv preprint doi: https://doi.org/10.1101/2020.11.14.20231142; this version posted November $16,2020$. The copyright holder for this preprint (which was not certified by peer review) is the author/funder, who has granted medRxiv a license to display the preprint in

It is made available under a CC-BY-NC 4.0 International license .

Table 3. Associations between capability well-being, depression, anxiety, social support, mental well-being and different types of vulnerabilities

\begin{tabular}{|c|c|c|c|c|c|c|c|c|c|c|}
\hline \multirow[t]{2}{*}{ Vulnerabilities } & \multicolumn{2}{|c|}{ OxCAP-MH score } & \multicolumn{2}{|c|}{ HADS-D score } & \multicolumn{2}{|c|}{ HADS-A score } & \multicolumn{2}{|c|}{ MSPSS score } & \multicolumn{2}{|c|}{ WHO-5 score } \\
\hline & $\beta(\mathrm{SE})$ & $95 \% \mathrm{CI}$ & $B(\mathrm{SE})$ & $95 \% \mathrm{CI}$ & $\beta(\mathrm{SE})$ & $95 \% \mathrm{CI}$ & $\beta(\mathrm{SE})$ & $95 \% \mathrm{CI}$ & $\beta(\mathrm{SE})$ & $95 \% \mathrm{CI}$ \\
\hline $\begin{array}{l}\text { Past mental health } \\
\text { treatment }\end{array}$ & $\begin{array}{r}-6.54 * * * * \\
(1.38)\end{array}$ & $-9.26,-3.82$ & $\begin{array}{r}1.97 * * * * \\
(0.47)\end{array}$ & $1.05,2.90$ & $\begin{array}{r}2.09 * * * * \\
(0.48)\end{array}$ & $1.16,3.03$ & $\begin{array}{r}-0.44 * * \\
(0.15)\end{array}$ & $-0.74,-0.15$ & $\begin{array}{r}-1.61 * * \\
(0.56)\end{array}$ & $-2.71,-0.50$ \\
\hline $\begin{array}{l}\text { Direct Covid-19 } \\
\text { experience }\end{array}$ & $\begin{array}{r}-4.58 * \\
(2.01)\end{array}$ & $-8.54,-0.62$ & $\begin{array}{r}1.23 \\
(0.69)\end{array}$ & $-0.12,2.58$ & $\begin{array}{l}1.53 * \\
(0.69)\end{array}$ & $0.18,2.89$ & $\begin{array}{r}-0.09 \\
(0.22)\end{array}$ & $-0.49,0.35$ & $\begin{array}{r}-1.59 * \\
(0.82)\end{array}$ & $-3.20,0.00$ \\
\hline $\begin{array}{l}\text { Indirect Covid-19 } \\
\text { experience }\end{array}$ & $\begin{array}{r}-0.11 \\
(1.29)\end{array}$ & $-2.65,2.43$ & $\begin{array}{r}0.25 \\
(0.44)\end{array}$ & $-0.61,1.12$ & $\begin{array}{l}0.97 * \\
(0.45)\end{array}$ & $0.09,1.85$ & $\begin{array}{r}-0.31 * \\
(0.14)\end{array}$ & $-0.59,-0.04$ & $\begin{array}{r}0.04 \\
(0.53)\end{array}$ & $-0.99,1.08$ \\
\hline Critical worker & $0.08(1.12)$ & $-2.13,2.30$ & $\begin{array}{r}-0.33 \\
(0.38)\end{array}$ & $-1.08,0.43$ & $\begin{array}{r}-0.32 \\
(0.39)\end{array}$ & $-1.09,0.44$ & $\begin{array}{r}-0.07 \\
(0.12)\end{array}$ & $-0.30,0.17$ & $\begin{array}{l}-0.49 \\
(0.45)\end{array}$ & $-1.38,0.40$ \\
\hline Constant & $\begin{array}{r}68.90 * * * \\
(4.83)\end{array}$ & $\begin{array}{r}59.41 \\
78.38\end{array}$ & $\begin{array}{r}3.08 \\
(1.65)\end{array}$ & $-1.15,6.32$ & $\begin{array}{r}6.44 * * * \\
(1.66)\end{array}$ & $3.17,9.71$ & $\begin{array}{r}6.11 * * * \\
(0.51)\end{array}$ & $5.11,7.12$ & $\begin{array}{r}16.35 * * * \\
(1.93)\end{array}$ & $\begin{array}{r}12.55 \\
20.15\end{array}$ \\
\hline
\end{tabular}

Note: Standard errors (SE) in parentheses $* \mathrm{p}<0.05, * * \mathrm{p}<0.01, * * * \mathrm{p}<0.001$; Statistically significant coefficients ( $\mathrm{p}<0.05)$ in bold; OxCAP-MH - Oxford CAPabilities questionnaire-Mental Health; HADS-D - Hospital Anxiety and Depression Scale Depression subscale; HADS-A - Hospital Anxiety and Depression Scale Anxiety subscale; MSPSS - Multidimensional Scale of Perceived Social Support; WHO-5 - World Health Organisation-Five Wellbeing Index 
medRxiv preprint doi: https://doi.org/10.1101/2020.11.14.20231142; this version posted November 16,2020 . The copyright holder for this preprint (which was not certified by peer review) is the author/funder, who has granted medRxiv a license to display the preprint in

It is made available under a CC-BY-NC 4.0 International license.

Table 4. Associations between capability well-being and current depression (HADS-D), anxiety (HADSA) and social support (MSPSS) levels

\begin{tabular}{lcr}
\hline & \multicolumn{2}{c}{ OxCAP-MH } \\
\cline { 2 - 3 } & \multicolumn{1}{c}{$\beta(\mathrm{SE})$} & $95 \% \mathrm{CI}$ \\
\hline HADS-D & $-1.76(0.10)^{* * *}$ & $-1.97,-1.56$ \\
HADS-A & $-1.48(0.05)^{* * *}$ & $-1.70,-1.27$ \\
MSPSS & $3.67(0.38)^{* * *}$ & $2.92,4.45$ \\
\hline
\end{tabular}

Note: $* \mathrm{p}<0.05, * * \mathrm{p}<0.01, * * * \mathrm{p}<0.001$; Analyses adjusted for age, gender, migration status, education level, children, employment, at risk group for Covid-19, employment status affected by Covid-19, past mental health treatment; OxCAP-MH - Oxford CAPabilities questionnaire-Mental Health; HADS-D - Hospital Anxiety and Depression Scale Depression subscale; HADS-A - Hospital Anxiety and Depression Scale Anxiety subscale; MSPSS - Multidimensional Scale of Perceived Social Support; WHO-5 - World Health Organisation-Five Wellbeing Index 